\title{
Affordability and Disconnections Challenges in Implementing the Human Right to Water in Portugal
}

\author{
Paula Duarte Lopes \\ CES-FEUC-University of Coimbra, 3004-512 Coimbra, Portugal; pdl@fe.uc.pt \\ Received: 1 December 2019; Accepted: 25 February 2020; Published: 2 March 2020
}

\begin{abstract}
Although the Human Right to Water and Sanitation (HRtWS) has been recognised by the United Nations and several countries have reformed their constitutions and/or national legislation to reflect this decision, several others, namely developed countries, have not reacted domestically to this recognition. The argument usually lies with the high level of institutionalisation of economic, social and cultural rights in these countries. However, reports of water disconnections due to payment default, especially in times of economic crisis and austerity policies, raise the issue of what does the implementation of the HRtW imply in countries where physical accessibility is almost fully guaranteed. The discussion seems to then focus on issues of affordability. This article focuses solely on the dynamics of implementing the Human Right to Water, because once the physical accessibility to sanitation is guaranteed, even if the service is deemed unaffordable and payment default ensues, disconnection of sewage collection per se does not occur. This does not imply that there are no issues associated with sanitation services in Portugal, but that those issues are of a different nature and beyond the scope of this article. Portugal does not have an explicit recognition of the HRtWS in its legal framework, but voted in its favor in the United Nations General Assembly and it is also a party to the International Covenant on Economic, Social and Cultural Rights. Thus, in Portugal, a country with $96 \%$ of the population connected to drinking water services, the $\mathrm{HRtW}$ is considered a non-issue. The article, however, argues that the HRtW in Portugal is not fully implemented and that issues of affordability hinder its respect, protection and fulfillment. The discussion builds on research conducted after the economic crisis period (2010-2014), since during those challenging years, the country faced a high number of households being deprived of access to water due to payment default. The dynamics of this period show that the core issue underlying the recognition of a HRtW still remains in Portugal.
\end{abstract}

Keywords: Human Right to Water; affordability; disconnections; social tariffs; Portugal

\section{Introduction}

This article addresses the realization of the Human Right to Water (HRtW) in Portugal. Portugal does not have an explicit recognition of the HRtWS in its legal framework, but voted in its favor in the United Nations General Assembly and it is also a party to the International Covenant on Economic, Social and Cultural Rights. The exclusive focus of this article on the HRtW is explained by the fact that once physical accessibility is provided, even if there is payment default, sewage collection per se is not disconnected. In Portugal, there are challenges to guarantee universal access to sanitation services, but the dynamics regarding affordability, potential for payment default and disconnection are of a different nature from the one regarding the HRtW. Portugal upholds a HRtW framework composed by formal laws that either recognize Human Rights pertinent to the HRtW or address water governance aspects from which the HRtW can be inferred. Political efforts to promote the actual recognition of the HRtW in the country have not made it to the headlines and have gone unnoticed to the majority of the population. Any contestation regarding water disconnections, if it 
does make it to the news, it is usually presented as a very localised issue. In Portugal, in general terms, the HRtW is considered a non-issue by most governmental officials and researchers, as well as by the population at large. And still, reports on water disconnections due to payment default keep cropping up. There seems to be a paradox between this seemingly 'non-issue' stance and this HRtW violation. According to the General Comment no. 15 of the United Nations Committee on Economic, Social and Cultural Rights, disconnecting water services due to the inability to pay constitutes a Human Right's violation [1].

In order to better grasp these dynamics and assess this paradox, in terms of its intensity and importance, this article discusses the issue of affordability of water services and its relation to the implementation of the HRtW in Portugal. It should be noted that the Special Rapporteur for the Human Right to Water and Sanitation also identified the issue of affordability and of assessing the institutional water arrangements from a human rights perspective as important aspects in implementing the HRtW in Portugal [2]. For this effect, the research builds on an analysis of water access during the economic crisis 2010-2014 in Portugal. First, because it is in times of rapid change and exception that rights and obligations are challenged. Between 2011 and 2014, a Memorandum of Economic and Financial Policies (MEFP) was signed with a troika, encompassing the International Monetary Fund (IMF), the European Central Bank (ECB) and the European Commission, to bail out the country. Strict austerity measures were adopted in order to comply with the commitments set out in that MEFP. According to some, the Portuguese government adopted even stricter austerity measures than those required by the troika, using the MEFP "as a window of opportunity to pursue reforms that would have met tremendous opposition otherwise" [3]. This included the adoption of a strong neo-liberal market approach, within which full cost-recovery of public services was crucial. In terms of water services, this approach implied a fierce pressure for making water services in each water utility financially sustainable. And second, the policies adopted during this period resulted in severe social consequences, rapidly creating generalised conditions for payment default of basic services, which led to water disconnections throughout the country. Between 2010, 2nd trimester, and 2013, 1st trimester, around 500 thousand jobs were destroyed and the total number of unemployed increased $60 \%$, with young unemployed (15 to 24 years old) increasing 107\% [4]. These unemployment figures were not more overwhelming, because in 2011 and 2012, more than 220,000 people emigrated, 48\% and 57\%, with ages between 20 and 40, respectively [4]. To find similar figures in Portugal one needs to go back almost 50 years to the emigration peak of the 1960s [4]. The number of unemployed grew faster than the number of unemployment benefits' beneficiaries, thus the number of unemployed without any social support increased continuously since the beginning of 2010, until, at least, 2012 [5]. Due to the successive changes in the eligibility conditions for unemployment benefits and the growing number of long-term unemployed, the coverage rate of these social benefits fell from 60\% in March 2010 to $40 \%$ in March 2013 [4]. The growing social unprotection was also reflected in the reduction of the number of Family Allowance beneficiaries (-33\% between March 2010 and October 2013) and of Social Inclusion Income beneficiaries (-37\% between March 2010 and October 2013) [4]. Consequently, focusing on the dynamics regarding the guarantee of the HRtW during those years of exception provides insightful information for a structural reflection on the guarantee of the HRtW in Portugal today.

Portugal is a relatively small country of around 10 million people [6], with a Gross Domestic Product (GDP) of around 204 billion Euros in 2018 [7] and a Human Development Index of 0.85 in the same year [8]. In terms of water access, Portugal has $96 \%$ of its population connected to a public water supply system and around 84\% connected to a sewage system [9]. All goes well, when all is well, but, in times of crisis, is when one expects all the safety guards created to be activated. Even more so when it comes to Human Rights. When in 2010, the Human Right to Water and Sanitation was recognized by the United Nations General-Assembly (Resolution 64/292) and Human Rights Council (Resolution 15/9), Portugal was already facing an economic crisis. In 2012, Portuguese media reports started denouncing the increasing dire conditions under which Portuguese families were living, including in terms of water access: "Families cannot even pay for water" [10]; "Without water, without light, without gas" [11]; 
"Requests for help to pay water, light and gas increase 40\%" [12]; "There are families breaching meters to get around water debts" [13]; "Water disconnections due to debts return with strength to the Porto neighborhood of Aldoar" [14]. Reports stated that in six cities alone, 3,000 families were disconnected from water services every month [10], and that this was happening with different intensities all over the country, including in the archipelagos [13]. An in-depth analysis of eight households showed that to survive, more and more Portuguese were stealing water in gas stations, using oil lamps, and eating only what did not need to be cooked [11]. And yet, no major social uproar took place; no political statement was made; no widespread disturbance was registered.

This article addresses the following question: is the Human Right to Water in Portugal being respected, protected and fulfilled? The analysis of the Portuguese case calls our attention for the fact that the existence of an institutional framework upholding the HRtW may not be enough to guarantee the respect, protection and fulfilment of that same Human Right. In fact, the analysis of the HRtW situation, during the 2010-2014 economic crisis in Portugal, suggests that the HRtW framework fell short due to a strong neo-liberal market-oriented approach adopted, and that currently the potential for the violation of the HRtW remains. The HRtW is framed within a neo-liberal market-oriented approach in which the services' financial sustainability constitutes a cornerstone of the whole framework [2]. Consequently, most of the discussions on the implementation of the HRtW in developed and liberal democratic countries focuses on issues of affordability. The cost-recovery and beneficiary pays principles of this neo-liberal market-oriented approach seem to override the guarantee of the HRtW per se, when payment default occurs [2]. The prevention of a massive violation of the HRtW during the austerity period was guaranteed by municipal actors, who imbued by a strong normative sense of what a HRtW implied in practice, decided to give priority to this norm instead of the neo-liberal market-oriented principles above identified, against their own legal and economic interests. However, after the crisis, with the economic improvement of households' situations and the subsequent decrease of water payment defaults, water governance dynamics resumed according to the institutional framework in effect. It is this framework that is being questioned in this article, since it confers primacy to the financial sustainability of the water services, including a strong beneficiary pays principle to water supply. In Portugal, water services are paid for, and although citizens have the right to have access to public water services, they also have the obligation to pay for these services, beyond their fiscal contributions. Consequently, the discussion, when it does occur, ends up jammed in affordability interpretations, which, although relevant, usually result in a highjack of the fundamental debate into a private versus public one, rendering the effective guarantee of the HRtW debate invisible. The Portuguese case highlights the potential fragility of HRtW institutional frameworks in so-called developed and liberal democratic countries.

\section{Materials and Methods}

In order to answer the overall research question-is the Human Right to Water in Portugal being respected, protected and fulfilled?-, the study was organized around three sub-questions that informed the different phases of research in terms of materials and methods adopted:

(1) What was/is the existing HRtW institutional framework in Portugal, both during the economic crisis period and currently? The objective was to identify if there had been any changes in the HRtW institutional framework in Portugal that would suggest that the economic crisis period was an exception and that currently the HRtW in Portugal is guaranteed.

(2) What was the magnitude of water disconnections during the economic crisis? This phase of research was focused on clarifying if the reports of water disconnections due to payment default were actually accurate and significant or not.

(3) What were/are the mechanisms and procedures activated to guarantee the HRtW? In order to understand the current status of the HRtW's implementation in Portugal, it is crucial to identify the existing mechanisms and procedures to uphold the HRtW and the results of their activation. 
The first phase aimed at mapping the formal laws and regulations, the actors involved and their roles and responsibilities, and the existing norms in terms of guaranteeing water access derived from international and national commitments, as well as local procedures. For this effect, the information was collected at three levels:

(1) At the international level-Since Portugal has not transposed to its domestic legal framework the HRtW, the team focused on identifying the international legal commitments pertinent to the HRtW that Portugal was a part of. We identified all the international treaties related to Human Rights that Portugal has ratified (see Table 1) and its vote on the HRtW in United Nations General-Assembly [15].

(2) At the national level-The team analysed the national legislation on basic rights and water governance [16-19], since different aspects of these elements are pertinent to understand the HRtW implementation in Portugal. An analysis of different policy proposals relevant to the HRtW and their discussion in the National Parliament, as well as the strategic plan for the water supply and wastewater services' sector was also conducted [20,21].

(3) At the local level-The team analysed the regulations of each water utility (272 regulations of the existing 287, in 2014) regarding its service and how payment default is addressed when households do not have the funds to pay for the service (most of these regulations are available on each utility's webpage). The documental analysis was complemented by a literature review of scientific articles on the organisation of the Portuguese water sector and the issue of tariffs and economic accessibility, allowing us to better understand what is in effect in terms of the HRtW implementation in Portugal.

The second phase aimed at identifying the magnitude of water disconnections that occurred throughout the country during the economic crisis period (2010-2014). Building upon the situation during the economic crisis period is relevant due to the concentration of water disconnection reports during that period and the fact that, during this period, the conditions created to guarantee the HRtW were fully tested due to the generalized economic hardship. The team wanted to obtain the number of monthly average disconnection notifications and the number of actual disconnections performed before and after 2010 (until 2014). These data would allow to better map the scale and intensity of the issue, as well as its distribution. However, due to the lack of reliable and accessible information from the water utilities, this analysis was not possible. As a means to mitigate this situation, and in order to at least obtain a general sense of what happened, the team decided to elaborate a questionnaire directed at water utilities' front office employees. The team wanted to obtain information regarding how these employees perceived what happened, based on their experience at the front office of each water utility and having to deal first-hand with water payment default, debts collection, disconnection notifications and actual disconnections. The questionnaire targeted all the water utilities' front offices in Portugal (287 in 2014), which were initially identified based on each water utility's webpage and then confirmed through a phone call. The questionnaire was then sent via email and a follow-up phone call was made to confirm reception and request an answer within the deadline stipulated. The questionnaire included three groups of questions: first, on the water utility's characterization; second, on its socio-economic and geographical context of operation; and third, on the employees' perception regarding the impact of the economic crisis and the existing means that could be activated for situations of economic hardship. The questionnaire included yes/no questions as well as questions to be answered based on a given selection of possibilities. On the specific topic regarding the economic crisis impact on households' payment default, the questionnaire included five questions asking the respondent to provide their opinion and eleven others asking the respondent to describe the rules that applied and, when possible, to quantify the current number of households in that situation. The five questions focusing on the respondents' perceptions included a yes/no question on whether they considered that the economic crisis had an impact on water payment default; two questions regarding their assessment of the evolution of the monthly average number of disconnection notifications and of actual disconnections 
performed, before 2011 and in 2014, with a given selection of possibilities (increased, maintained, decreased); and two open questions, immediately after each of the previous two questions, asking the respondent to identify the reasons and make a comment to the answers provided. The answers to the questionnaire (167 out of 287) were examined based on a simple statistical analysis.

After analysing the results from the questionnaire, a third research phase was developed with a two-fold objective. On the one hand, the team wanted to test how reliable the questionnaires' results were, i.e., whether the increase in disconnection notifications had not really matched the increase in actual disconnections, as suggested. And, on the other hand, the team wanted to understand what were the mechanisms or procedures used to prevent a higher number of disconnections, their relation to the existing HRtW institutional framework, and why they were activated, i.e., how they related (or not) to the actual HRtW. For this effect, the team conducted 43 face-to-face qualitative in-depth interviews, between November 2014 and February 2015. The 43 water utilities interviewed were identified resorting to criterion, convenience and maximum variation sampling strategies. Thus, they represent $15 \%$ of all water utilities and are divided between $93 \%$ of public utilities and $7 \%$ of private ones, reflecting a small bias towards public utilities (the national figures are around $90 \%$ of public utilities and $10 \%$ of private ones)-maximum variation sampling. These did not include the Autonomous Regions of Azores and Madeira (due to financial reasons-convenience sampling) nor the district of Faro (Algarve), since the region registers extreme peak consumption seasons with a high number of secondary homes, which the team considered would influence the overall results of the study-criterion sampling. The 43 interviews reflect the diversity of Portuguese water utilities' universe since their selection was based not only on their public/private capital, but also on several other socio-economic and socio-political criteria—criterion sampling-in order to include water utilities located both in urban and rural areas, in coastal and interior regions, in contexts characterized by higher and lower unemployment rates, by higher and lower ageing indexes, by high and low numbers of individuals receiving the Guaranteed Minimal Income and the Social Inclusion Income, as well as by higher and lower levels of industrialisation. The sample also took into account the political party of the Municipal executive during most of the economic crisis in order to mitigate any potential bias in terms of (non)alignment with governmental positions by default. The 43 interviews also resulted from reaching data saturation. After guaranteeing the maximum variation sampling strategy, the team concluded that no new information was being collected, dictating the conclusion of this research phase. The discourse used in the interviews was analysed to identify the language used to describe the situation and the reasons underlying the choice of words; to understand who was deciding the rules for what was being implemented or not; to understand who was deciding what could be said or not about the situation. Additionally, the interviews also allowed for a restricted narrative analysis in which the actors responsible for the situation, their goals, their agency, the timing of the situation and the actual situation were identified.

\section{Results}

The results of the study allow for the characterization of the HRtW institutional framework in Portugal derived from a multi-level analysis (international, national and local). This institutional framework is composed, at the international level, by legal commitments assumed by Portugal regarding Human Rights in general and by the fact that Portugal voted in favour of Resolution 64/292 in 2010 at the United Nations General-Assembly, recognizing the Human Right to Water and Sanitation. At the national level, this framework is composed by formal laws that either recognize Human Rights pertinent to the HRtW or address water governance aspects from which the HRtW can be inferred. It should be noted that in general terms, both governmental officials and the population at large consider the HRtW in Portugal a non-issue, arguing that it is obviously guaranteed, since $96 \%$ of the population is connected to drinking water services [9]. This level of analysis also presents the actors involved in water supply and in regulating water utilities' activities, therefore, with responsibilities in upholding the HRtW, or at least monitor its guarantee. There have also been some legal initiatives 
in order to nationally recognize the HRtW, but without success. The local level includes specific regulations and procedures that affect the implementation of the HRtW on a daily basis. This level of analysis includes the norms that shape the behaviour of those in charge of (dis)connecting water services, defining water prices and collecting water debts, i.e. local practices that affect everyday people in terms of their access to water.

\subsection{International Level}

Portugal has ratified all the major international treaties and adopted the Universal Declaration of Human Rights from which a Human Right to Water can be inferred (see Table 1).

Table 1. Major international treaties ratified and declarations adopted by Portugal.

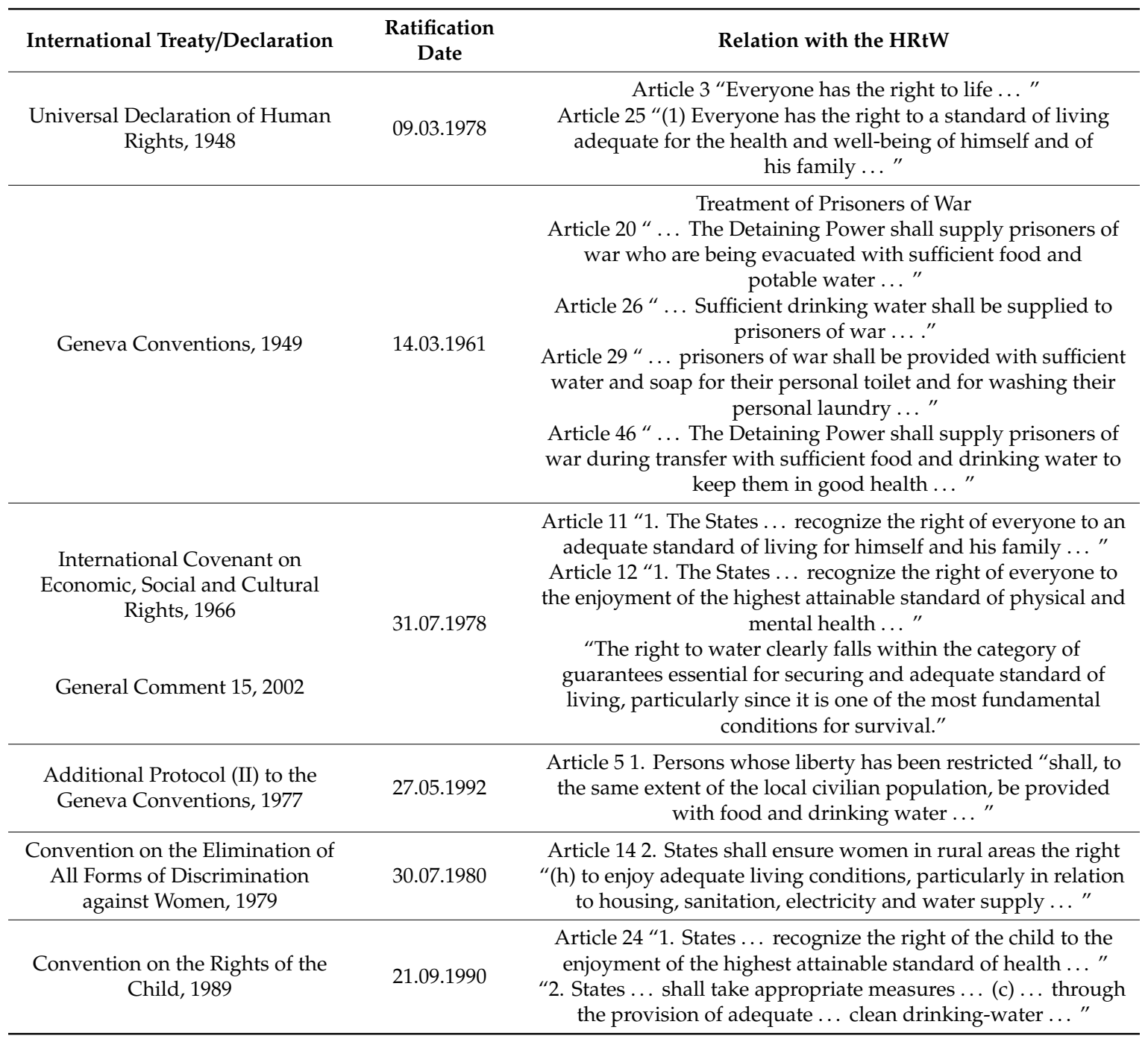

And although Portugal has voted in favour of the United Nations General Assembly Resolution Resolution 64/292, recognising the HRtWS, it has not legally transposed this Resolution into national legislation [15]. Still, one can conclude that Portugal is in favour and has adopted the Human Right to Water as a principle that should guide decision-making and practices nationally, based on its international commitments. 


\subsection{National Level}

As stated above, although Portugal has not transposed to its national legislation the HRtW, the national institutional framework reflects the commitment to respect, protect and fulfil the HRtW. The Portuguese Constitution states that human life is inviolable, as is the moral and physical integrity of individuals [16]. Water supply is considered a public service since 1996 and, consequently, cannot be disconnected without certain criteria being met, such as, the user needs to receive a prior notice, needs to be given 20 days before the disconnection occurring, needs to be informed of the reason for disconnection and of the procedures to avoid it [17]. The Water Law of 2005, which transposes the European Union's Water Framework Directive (2000), states that water management must observe several principles, including "(a) the Principle of water's social value, which consecrates the universal access to water for basic human needs, at a socially acceptable cost ... " and "(d) the Principle of water's economic value, through which is recognized the current or potential scarcity of this resource and the need to guarantee its economically efficient use, with the recovery of water services' costs, even regarding the environment and the resources, and being based on the polluter pays and beneficiary pays principles ..." [18]. The cost recovery aspect is specifically addressed in legislation concerning the economic and financial regime of water resources. This legislation establishes that all water users need to pay tariffs and that these "should allow for the recovery of costs associated to the supply of these services, in efficient conditions ..., guarantee transparency in tariff formation and the economic and financial equilibrium of each service rendered by the water utilities" [19]. None of these aspects are per se incompatible with the HRtW. In fact, they have been fully acknowledged and addressed in different documents and publications on this topic [20-23]. In all these instances, and because it is recognized that "there is an inconsistency in that utilities are expected to deliver services on a commercial basis but at the same time provide an affordable public good" [20], the need to structure tariffs in order to guarantee that no-one is excluded due to affordability issues is clearly stated.

If one follows the five characteristics associated with the implementation of the HRtW, Portugal complies with all, in general terms. Water available is (so far) sufficient; there are strict legal criteria to be met regarding safety and a rigorous monitoring system is in place; water supply is considered culturally and socially acceptable; there is physical access guaranteed to $96 \%$ of the population [9]; and affordability is not considered an issue per se. According to some studies, water affordability is on average below the 3\% of household's income recommended by the Organisation for Economic Co-operation and Development (OECD): some authors calculate 0.7\% [24] whereas the Water and Waste Services Regulation Authority (ERSAR) calculates $0.36 \%$ [25]. Consequently, affordability is not considered an issue in Portugal, which leads to several authors stating that, therefore, the HRtW is effectively implemented [26]. Additionally, the first $10 \mathrm{~m}^{3}$ consumed are usually charged at a very low price (or even for free) corresponding to the essential minimum quantity, which, according to some authors, represents a very good result from a social point of view [27].

Since the recognition of the HRtWS in 2010, several legal initiatives have been presented to and discussed at the National Parliament, proposing either the national recognition of the HRtW or water governance issues with an impact on the implementation of a HRtW [28]. Some of these initiatives include an explicit reference to the HRtW (see Table 2), whereas others do not (see Table 3).

All of these initiatives were systematically rejected. It is visible that the dynamics of initiatives occurred in phases, in which a political party's proposal triggered other parties' initiatives. The discussion of these initiatives was always temporally close to initiatives that focused on the public|private debate (see Table 3), which did not have an explicit reference to the HRtW. The minutes of the discussions and the various political and legal opinions regarding each initiative always refer to this public|private debate, without really delving into the issue of the HRtW. In fact, most attempts to focus on the HRtW ended up in an exercise of arguments' exchange for and against the privatization of water services. 
Table 2. Legal initiatives with an explicit reference to the HRtW.

\begin{tabular}{|c|c|c|c|}
\hline Legal Initiative & Date & Content & Proponent \\
\hline Bill 358/XIII & 16.12 .2016 & $\begin{array}{l}\text { Protection of individual and common } \\
\text { rights to water }\end{array}$ & $\begin{array}{c}\text { Portuguese } \\
\text { Communist Party }\end{array}$ \\
\hline Draft Resolution 584/XIII & 16.12.2016 & $\begin{array}{l}\text { Guarantees the right to water } \\
\text { and sanitation }\end{array}$ & Green Party \\
\hline Bill 335/XIII & 21.10 .2016 & $\begin{array}{l}\text { Protection of individual and common } \\
\text { rights to water }\end{array}$ & Left Block Party \\
\hline Bill 821/XII & 13.03.2015 & $\begin{array}{l}\text { Adopts the principle of the } \\
\text { non-privatization of the water sector }\end{array}$ & Green Party \\
\hline Bill 821/XII & 13.03.2015 & $\begin{array}{l}\text { Guarantees the public management of } \\
\text { water supply, sanitation and solid waste }\end{array}$ & Left Block Party \\
\hline Bill 698/XII & 03.12 .2014 & $\begin{array}{l}\text { Guarantees the right to access water } \\
\text { and energy }\end{array}$ & Left Block Party \\
\hline Bill 368/XII & 28.02.2013 & $\begin{array}{l}\text { Protection of the individual and common } \\
\text { rights to water }\end{array}$ & Citizens' Initiative \\
\hline Bill 366/XII & 27.02.2013 & $\begin{array}{c}\text { Guarantees the right to access water } \\
\text { and energy }\end{array}$ & Left Block Party \\
\hline Draft Resolution 583/XII & 18.01.2013 & $\begin{array}{l}\text { National Referendum to the privatization } \\
\text { of the water supply and wastewater sector }\end{array}$ & Left Block Party \\
\hline Draft Resolution 380/XII & 21.06.2012 & $\begin{array}{l}\text { Guarantees the right to universal access } \\
\text { to water and sanitation }\end{array}$ & Left Block Party \\
\hline Draft Resolution 360/XII & 05.06 .2012 & $\begin{array}{c}\text { Guidelines aiming at an economic, social, } \\
\text { environmental and financial } \\
\text { sustainability of water supply and } \\
\text { sanitation public systems... }\end{array}$ & Socialist Party \\
\hline Draft Resolution 346/XII & 25.05 .2012 & Human Right to Water and Sanitation & Green Party \\
\hline Draft Resolution 70/XII & 12.09 .2011 & $\begin{array}{c}\text { National Referendum to the privatization } \\
\text { of Águas de Portugal }\end{array}$ & Left Block Party \\
\hline
\end{tabular}

Table 3. Legal initiatives without an explicit reference to the HRtW.

\begin{tabular}{cccc}
\hline & Date & Content & Proponent \\
\hline Draft Resolution 493/XIII & 07.10.2016 & $\begin{array}{c}\text { Improvement of citizens' access to water, } \\
\text { sanitation and solid waste public services }\end{array}$ & $\begin{array}{c}\text { Portuguese } \\
\text { Communist Party }\end{array}$ \\
\hline Bill 116/XIII & 29.01 .2016 & $\begin{array}{c}\text { Inhibits the marketization of water supply, } \\
\text { wastewater and urban solid waste }\end{array}$ & $\begin{array}{c}\text { Portuguese } \\
\text { Communist Party }\end{array}$ \\
\hline Bill 819/XII & 12.03 .2015 & $\begin{array}{c}\text { Inhibits private companies from water } \\
\text { supply, wastewater and urban solid waste } \\
\text { activities }\end{array}$ & $\begin{array}{c}\text { Portuguese } \\
\text { Communist Party }\end{array}$ \\
\hline Bill 332/XII & 18.01 .2013 & $\begin{array}{c}\text { Inhibits private companies from water } \\
\text { supply, wastewater and urban solid waste } \\
\text { economic activities }\end{array}$ & $\begin{array}{c}\text { Pommunist Party } \\
\text { Draft Resolution 469/XII }\end{array}$ \\
\hline Bill 270/XII & 03.10.2012 & $\begin{array}{c}\text { Guarantee the public management of water } \\
\text { and solid waste }\end{array}$ & Left Block Party \\
\hline Bill 260/XII & 16.07 .2012 & $\begin{array}{c}\text { Guarantee the public management of water } \\
\text { and solid waste }\end{array}$ & Left Block Party \\
\hline
\end{tabular}

Since 2010, only three initiatives were approved (Table 4) and none transposes the HRtW into Portuguese legislation. They do, however, refer to different aspects that may have an impact on the full implementation of the HRtW in Portugal. 
Table 4. Legal initiatives approved with an explicit reference to the HRtW.

\begin{tabular}{ccccc}
\hline Legal Initiative & $\begin{array}{c}\text { Submission } \\
\text { Date }\end{array}$ & Content & Proponent & $\begin{array}{c}\text { Date of } \\
\text { Publication }\end{array}$ \\
\hline $\begin{array}{c}\text { Draft Resolution } \\
\text { 482/XII }\end{array}$ & 23.09 .2016 & $\begin{array}{c}\text { Automatic application of social } \\
\text { tariffs to water services as for energy }\end{array}$ & Left Block Party & 15.11 .2016 \\
\hline Bill 15/XIII & 04.11 .2015 & $\begin{array}{c}\text { Adopts the principle of the } \\
\text { non-privatization of the water sector }\end{array}$ & Green Party & 19.06 .2017 \\
\hline $\begin{array}{c}\text { Draft Resolution } \\
\text { 352/XII }\end{array}$ & 31.05 .2012 & $\begin{array}{c}\text { Promotes the accessibility, } \\
\text { sustainability and quality of water } \\
\text { and sanitation services }\end{array}$ & Ruling Coalition & 10.08 .2012 \\
\hline
\end{tabular}

The 2012 Draft Resolution presented by the Ruling Coalition (Social Democrat Party and Christian Social Democrat-People's Party) focused on issues of accessibility, sustainability and quality of water and sanitation services. With its approval, the National Assembly recommended the Government the establishment of social tariffs "to guarantee that no-one is deprived of access to water and sanitation services due to their economic or social situation" [29]. In 2016, the National Assembly approved the Left Block Party Draft Resolution and recommended the Government to extend to water services the mechanism created to automatically assign social tariffs to energy [30]. The Green Party Bill submitted in 2015, establishing the principle of non-privatization of the water sector, was adopted and became Law, constituting the fifth amendment to the 2005 Water Law [31], but only in 2017. Although no in-depth research was conducted to fully comprehend this time gap between 2015 and 2017, it is acceptable to say that the assessment and voting process in between the National Assembly and the Specialised Commissions along with the fact that the discussion was held in articulation with Bill 116/XII proposed by the Portuguese Communist Party, on the inhibition of water supply, wastewater and urban solid water marketization, resulted in a delay of the Green Party Bill's actual voting. After the Portuguese Communist Party Bill was rejected, then the Green Party rewrote its Bill which was again discussed and finally approved in 2017.

In terms of actors with direct responsibilities in rendering water access operational, Portugal is characterized by a two-tier system: a system 'em alta' ('bulk') which includes the utilities that withdraw, treat and supply the utilities 'em baixa' ('retail'). Although the water utilities 'em alta' structurally affect the activities of the ones 'em baixa', this analysis only focuses on the latter ones, which are directly responsible for supplying water to the population at large. In Portugal, these water utilities come in various shapes and sizes. The vast majority is of a public nature (90\%), with around $10 \%$ being managed by private concessions (see Table 5 ).

Table 5. Water utilities 'em baixa' (2014).

\begin{tabular}{ccc}
\hline Type of Water Utility & Number & Percentage \\
\hline Public & 258 & 90.2 \\
\hline Municipal or municipalized services & 229 & 79.8 \\
\hline Municipal companies & 14 & 4.9 \\
\hline Public partnerships & 4 & 1.4 \\
\hline State company & 2 & 0.7 \\
\hline Mixed capital & 9 & 3.1 \\
\hline Private & 29 & 9.8 \\
\hline Total & 287 & 100 \\
\hline
\end{tabular}

Among the public water utilities, one can find various types of institutions: municipal or municipalized services $(79.8 \%)$, companies whose capital is fully owned by the respective municipality $(4.9 \%)$, companies with municipal and state, either national or regional, capital (public partnerships 
$(1.4 \%)$, companies fully owned by the state $(0.7 \%)$, and mixed capital companies $(3.1 \%)$, where public actors own the majority of the capital (and thus being considered for the purpose of this analysis as public).

In 2009, the Portuguese Government created a national Water and Waste Services Regulation Authority (ERSAR) to recommend and advise utilities on matters pertaining to the interpretation of the rules guiding the sector's management and the definition of tariffs [32,33]. ERSAR regulatory actions also aim to "protect correctly the users" by assuring that water provision respects quality standards and that tariffs are socially acceptable, considering the principles of universality and cost-efficiency [34]. It should also be noted that ERSAR identifies tools that have been created "to protect consumers, namely the poor population" at the specific level, such as the right to have access to the public water supply grid when it is available at less than 20 meters; the right to be served within five days of requesting water access; the "right to benefit from a social tariff (poor families)"; and the right to have an interrupted water supply 24 hours a day, every day of the year, except for "strong technical reasons or lack of payment (after due diligence procedures)" [35].

\subsection{Local Level}

Regarding the individual water utilities, a content analysis of these regulations was conducted, identifying if social and large family tariffs (or others) existed, mapping the procedures and the processes associated to payment default, and if access to water was respected, protected and fulfilled based on their regulatory framework. The results were diverse, although the majority did include some sort of social tariffs and specific procedures regarding payment default, processes are often confusing and/or ambiguous. None mentions the Human Right to Water. The questionnaire applied also included a question inquiring if the water utility offered a social or large family tariff. Of the 167 respondents, only 124 answered these questions with 60.5\% stating they offered a social tariff for low-income families and 53\% stating they offered a large family tariff. The ERSAR has to approve each water utility regulation and provides clear instructions regarding the need for social tariffs to be included.

As explained above, the questionnaire was sent to all water utilities in Portugal (287 in 2014), of which 167 replied. In face of a lack of quantitative information providing a clear picture of the magnitude of the disconnections being reported, the questionnaire aimed at collecting information regarding the perceptions of those working in the front-office of water utilities. For this effect, the respondents were specifically asked: 'How do you assess the evolution of the monthly average number of water disconnection notifications in 2014, when compared to the period before 2011?' and 'In comparison with the period before 2011, how would you assess the evolution of the monthly average number of water disconnections?' They were asked to mark one of the provided possible answers: increased, maintained or decreased, and to consider their area of service. The answers were then examined comparing public and private capital water utilities, based on the idea that private capital utilities would be more market-oriented than public capital ones and therefore the results could be significantly different. The results showed that the majority of respondents (65\% public and $64 \%$ private) had the opinion that the number of water disconnection notifications had increased between 2011 and 2014 (Figure 1), but that the number of actual water disconnections in the same period had not increased as much (53\% public and $27 \%$ private, see Figure 2 ).

The results also show that although there was a relatively smaller perception that disconnection notifications between 2011 and 2014 had decreased (both public and private, 9\%, see Figure 1), there was a rather higher perception from private companies' staff that water disconnections had actually decreased during this period (36.5\%, see Figure 2$)$. 


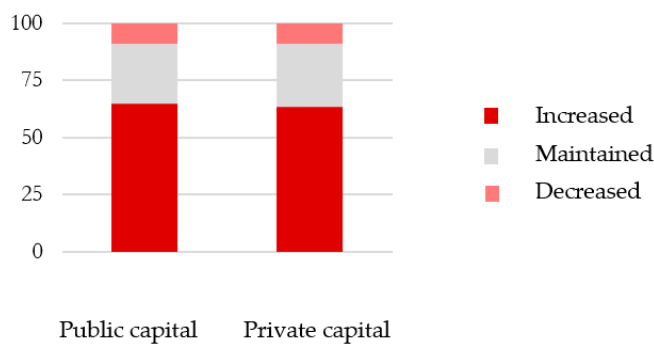

Figure 1. Percentage of respondents' answers regarding the evolution of the number of water disconnection notifications between 2011 and 2014.

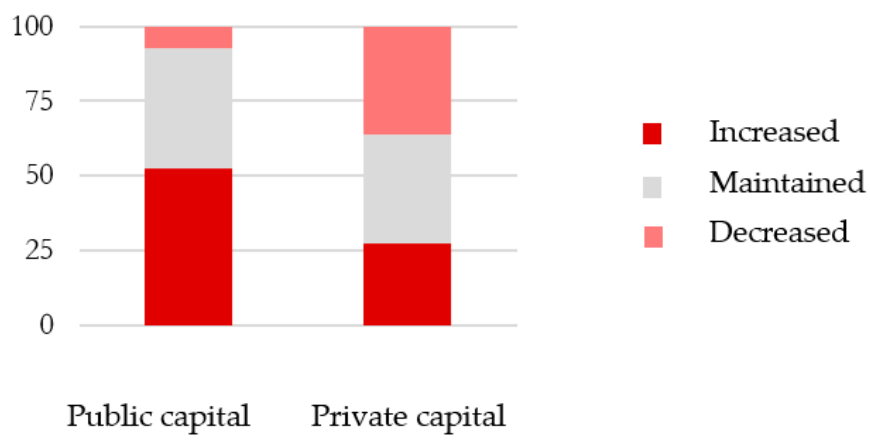

Figure 2. Percentage of respondents' answers regarding the evolution of the number of actual water disconnections between 2011 and 2014.

The questionnaire's results seemed to match the reports in the media. Still, they carried an intrinsic methodological problem and yet another challenge. Methodologically, these were just opinions of those working on water services' front-offices and although these had first-hand knowledge of the dynamics under analysis, there was no way of confirming if all potential respondents in any one water utility front-office would have answered the same way. These results provided a general and rather intuitive picture of what had happened, based on the experience of water services staff, allowing the team to 'feel the pulse' of water practitioners on this matter. These results also presented a new challenge, since it seemed that although the water disconnection notifications had increased, the actual number of disconnections had not. On the one hand, this could explain why there was no massive uproar in Portugal regarding this situation and maybe the HRtW institutional framework was strong enough after all to uphold this right, even in times of crisis. Still, it was of utmost importance to obtain concrete and reliable information regarding what had occurred, for the results would provide valuable information to assess the resilience of this framework. For this effect, the team conducted 43 in-depth interviews, which were extremely rich allowing us to better understand the divergence identified when analysing the questionnaires' results.

The face-to-face interviews provided detailed information on the works of the HRtW institutional framework mapped and the local practices concerning this right. Most of the times the interviews ended up being group-interviews with different staff members joining and contributing to the discussion that stemmed from the questions asked. The analysis of the interviews allowed for the identification of measures derived from the institutional framework that aimed at the respect, protection and fulfilment of water access rights by domestic users (social tariffs, large family tariffs, consumer protection measures against discretionary interruptions, measures regarding debt settlements, among others). But, more importantly, these interviews enabled the identification of non-institutionalised, ad-hoc measures adopted at the local level to promptly and effectively respond to the reality of an unexpected increased number of water payment defaults by domestic users, which ranged from inaction (not disconnecting, not reclaiming the payments defaulted) to creative responses (indirect payments, direct exchange, 'little black book'). 
Additionally, the interviewees presented a straight-jacket scenario within which water utilities seem to be operating in. The financing operational water services model includes a progressive full cost-recovery principle, the application of water tariffs to end-users and the principle of financial sustainability of water services. During the economic crisis, this situation became unfeasible, with public water utilities facing budget cuts, due to austerity measures, and a decrease in water tariffs' revenue, due to payment defaults, lower consumption levels and the volunteer disconnection of secondary homes. This willingness to disconnect secondary homes, i.e. willingness not to pay for water bills of secondary homes, was explained by being cheaper to reconnect for the holidays' period than paying the monthly bills throughout the year. The pressure to update water tariffs and strictly follow due diligence to collect water bills became unbearable [2]. Currently, the economic hardship has been mostly overcome and, in 2017, the Government issued a Decree-Law regarding social tariffs for water services [36], harmonizing its meaning and application criteria. Still, the application of social tariffs by the municipalities is voluntary; the municipality has to finance it and if the water utility is not municipal, the corresponding municipality has to finance the differential between the water tariffs in effect and the application of the social tariff [36].

\section{Discussion}

The analysis conducted shows that the Portuguese governance framework includes an unequivocal reference to the Human Right to Water, in its public services, water governance and management and economic and financial management regulations. The existing institutional framework for guaranteeing the Human Right to Water incorporates measures and procedures to uphold this Human Right (even if it does not always mention it as a Human Right). However, the co-existence of promoting the respect, protection and fulfillment of the $\mathrm{HRtW}$ with progressive full cost-recovery and beneficiary pays principles, as well as the financial sustainability of water services, has created a so-far unresolvable tension in the implementation of this institutional framework. This tension, during the economic crisis in Portugal (2010-2014) resulted in the violation of the Human Right to Water. The legislation and the legal initiatives analysed clearly illustrate that structural tension. On the one hand, water supply is a public service, should, therefore, abide by particular aspects in order to protect the users; but, on the other hand, water services must implement tariffs to progressively achieve full cost-recovery of its investments and working costs, and maintain that economic and financial sustainability (although also taking into account its social and environmental sustainability). The different elements are positioned on the same level of importance without taking into account the potential conflict that may occur when one cannot uphold all of those criteria at the same time and to the same level of compliance. Consequently, the institutional framework set up does allow for water disconnections due to payment defaults. Moreover, the mechanisms to prevent water disconnections due to the inability to pay are highly recommended, but not compulsory [36].

Most of the legislative initiatives that either proposed the national recognition of the HRtW or proposed changes to the current institutional framework with a potential impact on the assurance of the HRtW were systematically rejected, not because Parliamentary Deputies are against the HRtW or do not want it nationally recognized, but because most of the proposals included the primacy of the HRtW over economic and financial principles, denouncing the negative impact of the privatization of water and wastewater services. Albeit with different intensities, all proposals criticized the marketization of the water services. The government, which had the majority in the National Parliament, did not flinch in upholding the cost recovery and beneficiary pays principles for water services. The arguments included the recognized economic value of water resources and the European Union recommendations regarding the need to promote an efficient water sector, by charging water tariffs and adopting a cost recovery strategy. So, in fact, the discussion on the HRtW in Portugal, at that time, was contaminated by a more ideological discussion on the marketization/privatization of water services and the fact that the Memorandum negotiated with the troika was very much focused on cost recovery strategies, 
efficiency and a reduction of public expenses. Consequently, the context under which this discussion was held was not conducive to a clearer and more focused debate on the HRtW.

As for the reports on water disconnections that triggered this analysis, the information collected, particularly during the face-to-face interviews, provided a more detailed picture of local practices, which conferred primacy to the HRtW against governmental recommendations at that time. As presented above, the results from the study show that although there was a significant increase in water disconnection notifications during the economic crisis, the number of water disconnections did not increase in the same or similar amount. The underlying reasons can be found in the adoption of two groups of measures: institutionalised measures created to respond to structural situations, and non-institutionalised, ad-hoc, measures that were locally adopted to promptly and effectively manage the situation created by the economic crisis in Portugal.

\subsection{Institutionalised Measures}

The institutionalised available instruments, regarding the access to water services, include mechanisms that allow low-income users to access water services, and measures concerning consumer protection against discretionary service interruptions and debt settlements. Concerning the first type of measures, the former-IRAR (Water and Waste Regulatory Institute, currently ERSAR) issued a recommendation in 2009 related to price regulation, asking water utilities to continue to reflect in tariff structures the "principle of economic accessibility, according to which the tariffs should consider the financial capacity of users, contributing to the progressive universal access to water services" [37]. Additionally, IRAR recommended the elimination of fixed costs for users in economic need and the enlargement of minimum variable echelons, assuring economic accessibility while maintaining tariffs' progressiveness with the objective to moderate consumption. For this effect, the creation of social and large family tariffs was recommended. However, due to the diversity of water utilities and their operational and managerial independence in this area, there are important differences in how social and large family tariffs are being offered. There are differences concerning the requirements to access these options, as well as on the tariff structure. There are tariffs which exempt users from paying fixed costs [38] whereas others apply a discount on this component [39]. There are social tariffs which reduce the price of every echelon and tariffs which only reduce the price of lower and middle echelons [40].

Besides the tariffs for users with low-income, IRAR also recommended the availability of large family tariffs. The design of this option also varies according to different water utilities. First, it varies according to the different interpretations of the concept of large family. Although the Portuguese Society for Large Families defines it as families with five or more members [41], not all the water utilities use this definition. There are water utilities that make the distinction of large families starting with four members [42], whereas others, disregarding IRAR's recommendation, consider that economic factors, namely family income, should also be a requirement [43]. Concerning tariff structure, we also identified a wide variety of options. One of the most common is the fusion or enlargement of the first and second echelons [40], whereas other water utilities decide to apply a more complex progressivity, depending on the number of extra members in the family [44]. Finally, there are water utilities that also make available special water tariffs for the elderly or for the disabled $[43,45]$.

There is legislation that protects users in case of service interruption. Law 23/96 [17] which classifies water services as an essential public service, considers a number of mechanisms to protect final consumers. Concerning service interruption, the rules for this procedure are clearly defined. In its original form, the law obliged water service providers to notify, by letter, the user with eight days' notice prior to service interruption, as well as the steps the user should take in order to avoid service interruption. The mandatory number of days between user written notification and service interruption were enlarged in 2008 (Law 12/2008) to 10 days, and to 20 days in 2013 (Law 10/2013) [17]. After service interruption due to non-payment, several water utilities make available options for debt settlements. In most cases, there is a minimal debt value that needs to be met in order to have access to this process. Scheduling and debt restructuring processes vary across different water utilities. 
In cases of severe economic need and social distress there are a number of social mechanisms designed to help families and individuals. These systems operate at different levels. The central government works with the Social Security Institute, municipalities have their own social services, and private social welfare entities also help local populations. In terms of the centralised action of the Social Security, there are mechanisms that allow the identification of families in need. After an evaluation process, water and other household expenses may be paid, partially or in full, by the central government [46]. Municipalities also have, through their own social services, funds for families in need. In these cases, municipalities might pay water bills directly when the local water provider is private [47], or through cash transfers to families [48]. Besides public entities, there are also private welfare entities helping families in need, working alongside with public institutions [49]. A high-level employee of a private water utility stated that "the company is the one responsible for providing this service, and public authorities should be in charge of social issues" [47], stressing the positive cooperation between the company and the municipality.

There seems to be no major differences between public and private service providers in terms of institutionalised solutions. Both have social and large family tariffs, both are obliged to follow the same legislative and regulatory obligations in terms of service interruption, and both make available to customers the possibility of debt settlement options. It seems natural that water utilities controlled by municipalities tend to act more swiftly in terms of social issues and urgent matters due mainly to its organic integration and physical proximity with municipal social services [50]. Close proximity with the population and knowledge of local realities and dynamics are elements identified by civil servants and politicians responsible for administering municipal water utilities in order to justify their higher degree of responsiveness to increasing social problems in times of economic crisis. Proximity and knowledge are thus two of the reasons explain the existence of non-institutionalised practices, which contribute to assure that users that are unable to pay for water services might continue to have access to it.

\subsection{Non-Institutionalised Measures}

So, besides the aforementioned measures, the in-depth interviews allowed for the identification of a group of solutions that allowed consumers to continue to access water services even in case of non-payment and indebtedness. These measures present a different logic, somewhat contrary to the one previously analysed. The institutional logic seeks to assure that economically weak families and individuals may access water services through a series of mechanisms which will allow them to pay water bills, namely through special tariffs. However, if such payment is no longer possible, social mechanisms and actors are called into action, and they operate in a (co)payment logic. The rationale behind these ad hoc measures is different: they do not function in a preventive way, but mostly as a last resort. These measures are mostly visible in publicly run water utilities, in small-medium municipalities, but they co-exist throughout the country even in service areas under private concessions.

Before analysing these ad hoc solutions, there is also a group of impediments, non-intentional, non-planned and involuntary realities which might explain why a part of the population continued to access water services even in cases of non-payment. There are municipal water utilities that even when having the capacity and technical means to adequately bill their final users, they do not possess the capabilities to promote efficient debt collection processes [49]. Other water utilities do not have the capacity to implement measures that would allow them to monitor service interruption processes and these tend to occur in a non-systematised way. Sometimes, public employees responsible for service interruption, plumbers, warn their fellow citizens before proceeding with their task, giving them an opportunity to pay their debts and avoid this process [51]. There are municipalities that do not have the necessary structure to process bills, rendering impossible the establishment of proceedings concerning service interruption [52].

Besides the lack of capacity described above, there is a group of policies or ad hoc measures that are implemented, either at the political or technical level, that while not framed by law or in any regulation, 
constitute nevertheless a way of assuring access to water services by subjects and families in economic distress. First, measures or attitudes that are passive in their nature, this means, that produce effects by the voluntary inaction of certain actors concerning the application of certain mechanisms in case of non-payment. Some water utilities refuse to conduct any sort of service interruption due to reasons of economic difficulties. Two local representatives that requested to participate in the interviews in their municipality water services clearly expressed that no service interruption had ever been made in such cases [50,52]. One of them referred that the municipality had a non-collected debt of over $€ 50.000$, that was "outside the scope of the law", but that s/he would not allow for any service interruption because it was a social case [50]. Another elected representative declared that instead of promoting service interruption in these cases, all these situations were flagged as social problems, and directed to the municipality's social services [52]. The importance of municipal social services was mentioned by both officials. According to a technical staff from a municipal water utility, there are citizens that appeal directly to the mayor in order to avoid service interruption due to lack of payment [53]. Very often public authorities attend to these requests if they are considered legitimate and truthful, in a non-systematic and case-by-case basis [53]. Another municipal technical civil servant referred that in case of notorious and publicly known situations of economic fragility, there was a softening of the rules applied to payment and extension of deadlines for payments [49]. These possibilities exist due to the already mentioned proximity between local public powers and the population, as it was largely recognised by many interviewees.

Inaction and passivity may also play a role in the case of old debts accumulated by consumers. According to the Law of essential public services, water bills cannot be reclaimed by service providers after 6 months [17]. As described before, some municipalities do not have the capacity to operate debt collection structures, however, some of the debt that becomes uncollectable does so due to political choices, regarding socially fragile groups [50]. Some of the options available in institutionalised forms, in some water utilities, occur in a non-institutionalised way in others. They are invested by an ad hoc character, which reflects a high degree of autonomy and discretionary power of high-level civil servants. According to two public managers, the decision over allowing debt to be paid by monthly instalments, the number of monthly payments, etc., is designed case-by-case, and their continuity is dependent on the compliance with the deal made and the perceived degree of consumers' good-faith $[43,54]$. In these cases, the front-office has 'little black books' where the monthly instalments are registered. These decisions do not comply with the legislations regarding debt collection which establishes certain amounts and a fixed number of instalments to be applied.

Finally, a public manager from another municipal water utility declared that the municipality may propose unemployed citizens to perform social work in order to pay water debts [55]. An elected official told us that sometimes, in order to avoid service interruption, civil servants working in the water department may pay water bills of citizens they personally know [56]. The fact that water is seen as an essential good, whose access interruption leads to major inconvenience [48,50] and that there is a close relation of proximity between local representatives and their constituents, which enables faster and clearer communication and the possibility of assessing situations of economic need [56], may explain the existence of this type of non-institutionalised realities.

After the troika left, the context somewhat changed presenting a window of opportunity to rectify some of the issues identified during the crisis. For instance, to benefit from a social tariff, an individual used to have to apply with the municipality and provide their tax return from the previous year. This mechanism was too slow to face rapid socio-economic changes determining that too many households were considered ineligible during the economic crisis. Currently, the automatic application of social tariffs, for the municipalities that have adopted them, has been approved (2016), but still awaits implementation. Also, previously, each municipality that had adopted social tariffs could define it autonomously, creating unequitable situations among citizens under similar circumstances. Nowadays, municipalities that have adopted social tariffs have a specific Decree-Law detailing how these should be calculated and applied. Finally, with the amendment to the Water Law, adopting the 
principle of non-privatization of the water sector, it is possible, in theory, to steer the debate towards the HRtW in a more focused manner. This, however has not yet occurred.

\section{Conclusions}

The institutional framework regarding water access in Portugal analysed encompasses not only an unresolved tension between the HRtW principle and economic and financial management principles, but also a so-far unsustainable management system in which the water utilities end up bearing costs due to financial regulations that seem to be inadequate to water services reality and contradictory to upholding the HRtW.

In the last five years, the troika has left Portugal (in 2014) and the country seems to be recovering from the crisis, at least according to the most common economic indicators: $7 \%$ (2018) of unemployment rate, contrasting with $13.9 \%$ in 2014 [57]; $2.65 \%$ of real GDP growth rate in 2018, with $0.8 \%$ in 2014 [58]; and $121.9 \%$ (2018) of gross debt as percentage of GDP, compared with $132.9 \%$ in 2014 [57]. In 2015, a new strategy for water supply and wastewater was concluded (2014-2020), in which the HRtW is discussed as an integral part of the national water governance institutional framework [59]. It states that its attainment should not constitute a problem in the short-term, but that it should deserve attention so that its upholding does not question the financial and social sustainability of the service rendered [59]. The tension identified persists. The document clearly emphasizes that water access should be guaranteed to vulnerable population and income should not constitute a discriminatory element, but, at the same time, the focus is on social tariffs for that effect [59]. ERSAR has grown stronger in order to guarantee that all water utilities comply with the economic and financial principles of water governance-progressive full cost recovery, financial sustainability with inhibition of cross-sector financing, and municipal financing of social tariffs-, alongside the quality, social and environmental ones. In 2017, the National Parliament approved the principle of the nonprivatization of the water sector, establishing the public exploitation and management of water [60]. But still in 2017, the media reported that "Dozens of families in Aldoar are without water" [61]. The water utility stated it had disconnected illegal water connections and households that had been notified according to national legislation and regulations due to payment default [61]. Aldoar is an economic fragile neighborhood in Porto, but the Human Right to Water should still apply. As Ms. Catarina de Albuquerque, United Nations former-Special Rapporteur for the Human Right to Water and Sanitation, stated "Before deciding to roll back on people's rights ... it is possible to 'expand available resources'. What shouldn't be done is to cut to those that have the least, which, she guarantees, is a violation of human rights. 'Instead of protecting the disadvantaged we did the opposite'." [62].

The economic crisis that affected the so-called developed and liberal democratic countries gradually highlighted the importance of also monitoring the implementation of the HRtW in these countries. The possibility of exclusion due to non-payment has always existed, but in times of economic crisis, i.e., in times of exceptional conditions, this possibility has become a harsh reality. The States behind their institutional frameworks keep stating that there is no structural problem, but reality shows a different picture. The case of Portugal illustrates these dynamics. During the economic crisis 2010-2014, households had their income drastically reduced and, simultaneously, the government, first recommended, and currently legally imposed a full cost-recovery strategy to all water utilities. The institutionalised responses to non-payment situations quickly revealed to be ineffective. The ad hoc responses provided by municipalities (also in the case of private water utilities) were actually the effective mechanisms that guaranteed the fulfillment of the HRtW in Portugal. These could be considered expected responses to the crisis situation, since municipalities, although non-governmental, are nevertheless public. However, increasing debts and governmental audits have rendered these responses unsustainable in the longer run, rendering visible the fragility of the HRtW implementation in Portugal.

Since 2016 Portugal seems to have taken steps to strengthen the resilience of its HRtW institutional framework. However, some unresolvable issues remain. First, the possibility for water disconnections 
due to payment default is a fact. This aspect relates to what the HRtW means in the end. Does the State have the obligation to supply a minimum quantity of drinking water even if its citizens cannot or do not pay for those services? Although the legislation is clear that water services should be paid for, there are communities and neighborhoods where water utilities do not follow due diligence to collect water bills and do not disconnect the water service. Portugal needs to clearly define its position on this matter [2]. In some countries, such as Austria, France or Ireland, water disconnections due to payment default are not allowed [63]. Second, the adoption of mechanisms to minimize water disconnections due to payment default, namely the adoption of social tariffs, is a voluntary decision by each municipality. Without questioning municipal autonomy and democratic participation, if the Government can legally impose a full cost-recovery and a beneficiary pays principle, as well as the financial sustainability of the water services, if willing, it can also impose the adoption of social tariffs. Again, Portugal needs to step up and unequivocally recognize the Human Right to Water in national legislation. The challenge facing the HRtW implementation in Portugal, as in most so-called developed, democratic liberal countries, stems from the definition, application and monitoring of the affordability aspect of this Right. It is not an issue as visible as the lack of access to safely managed water services. But, exactly because it is rather deemed invisible and mainly referred to abstract statistical calculations, it is of utmost importance to not only monitor these contexts, but to also promote transparent and participative discussions on how citizens understand their Human Right to Water; on what affordability means beyond regional and national averages, focusing on lower income households and vulnerable groups and neighborhoods, in line with the Special Rapporteur's report on Portugal [2]; as well as on citizens' level of willingness to pay to have their HRtW guaranteed.

Funding: This research was conducted under the project "PPWater - Private and Public responses to default in water payments: the Portuguese case" funded by the Portuguese Science and Technology Foundation (EXPL/IVC-CPO/1094/2013| FCOMP-01-0124-FEDER-041144).

Acknowledgments: I acknowledge the contribution of members of the research team regarding the investigation conducted and the formal analysis of the information collected: Marisa Borges, António Leitão and Daniela Nascimento.

Conflicts of Interest: The author declares no conflict of interest. The funders had no role in the design of the study; in the collection, analyses, or interpretation of data; in the writing of the manuscript, or in the decision to publish the results.

\section{References}

1. United Nations Committee on Economic, Social and Cultural Rights. Substantive Issues Arising in the Implementation of the International Covenant on Economic, Social and Cultural Rights-General Comment No. 15 (2002): The right to water (arts. 11 and 12 of the International Covenant of Economic, Social and Cultural Rights); Committee on Economic, Social and Cultural Rights: Geneva, Switzerland, 2002.

2. Human Rights Council. Report of the Special Rapporteur on the Human Rights to Safe Drinking Water and Sanitation on His Mission to Portugal; Human Rights Council: Geneva, Switzerland, 2017.

3. Moury, C.; Freire, A. Austerity Policies and Politics: The Case of Portugal. Revue. Pôle Sud 2013, 39, 35-56. [CrossRef]

4. CRISALT. A Anatomia da Crise: Identificar os Problemas Para Construir as Alternativas. $1^{\circ}$ Relatório, preliminar, do Observatório Sobre Crises e Alternativas; Observatório Sobre Crises e Alternativas, Centro de Estudos Sociais, Universidade de Coimbra: Lisboa, Portugal, 2013. Available online: https:/www.ces.uc.pt/ficheiros2/files/ Relatorio_Anatomia_Crise_final__.pdf (accessed on 27 December 2019).

5. CRISALT. Barómetro das Crises No. 1 Desemprego e Emprego; Observatório sobre Crises e Alternativas, Centro de Estudos Sociais, Universidade de Coimbra: Lisboa, Portugal, 2012. Available online: https://www.ces.uc. pt/ficheiros2/files/Barometro_Crises_Desemprego_Emprego_1.PDF (accessed on 27 December 2019).

6. PORDATA-Base de Dados Portugal Contemporâneo. Available online: https://www.pordata.pt/en/Portugal (accessed on 27 December 2019).

7. PORDATA-Base de Dados Portugal Contemporâneo. Available online: https://www.pordata.pt/en/Portugal/ GDP+(2016)-130 (accessed on 27 December 2019). 
8. Human Development Indicators-Portugal. Available online: http://hdr.undp.org/en/countries/profiles/PRT (accessed on 27 December 2019).

9. PORDATA-Base de Dados Portugal Contemporâneo. Available online: https://www.pordata.pt/ en/Portugal/Population+connected+to+public+water+supply+systems++sewerage+systems+and+ wastewater+treatment+plants+(WWTP)+(percentage)-1187 (accessed on 27 December 2019).

10. Diário de Notícias. 17 July 2012. Available online: https://www.dn.pt/dossiers/tv-e-media/revistas-deimprensa/noticias/familias-ja-nem-agua-conseguem-pagar-2669922.html (accessed on 27 April 2019).

11. Visão, 22 Novembro 2012; no. 1029.

12. Diário de Notícias, 17 Julho 2012. Available online: https://www.dn.pt/portugal/pedidos-de-ajuda-para-pagaragua-luz-e-gas-sobem-40-2670485.html (accessed on 27 April 2019).

13. Jornal de Notícias; 18 July 2012. Available online: https:/www.jn.pt/economia/ha-familias-a-violar-contadorespara-contornar-dividas-com-a-agua-2671994.html (accessed on 27 April 2019).

14. Público, 21 Setembro 2012. Available online: https://www.publico.pt/2012/09/21/jornal/cortes-de-agua-pordividas-regressam-em-forca-ao-bairro-portuense-de-aldoar-25286201 (accessed on 27 April 2019).

15. United Nations General Assembly. Resolution recognising the Human Right to Water and Sanitation. Milestones, 28 July 2010.

16. Assembleia Constituinte. Constituição Portuguesa (Alterada pelo/a Lei Constitucional n. ${ }^{\circ}$ 1/2005-Diário da República n. ${ }^{\circ}$ 155/2005, Série I-A de 2005-08-12); Assembleia Constituinte: Lisboa, Portugal, 1976.

17. Assembleia da República. Lei dos Serviços Públicos-Lei n ${ }^{\circ} 23 / 1996$. In Diário da República n. $.^{\circ} 172 / 1996$, Série I-A de 1996-07-26: Lisboa, Portugal, 1996. Revised by Lei.$^{\circ}$ 12/2008, de 26/02, Lei n. 24/2008, de 02/06, Lei $n .^{\circ}$ 6/2011, de 10/03, Lei.$^{\circ}$ 44/2011, de 22/06 and Lei n. ${ }^{\circ}$ 10/2013, de 28/01; Assembleia da República: Lisboa, Portugal, 2013.

18. Assembleia da República. Lei da Água-Lei n. ${ }^{\circ}$ 58/2005. In Diário da República $n .^{\circ}$ 249/2005, Série I-A de 2005-12-29; Assembleia da República: Lisboa, Portugal, 2005.

19. Ministério do Ambiente. do Ordenamento do Território e do Desenvolvimento Regional. Decreto Lei n 97/2008. In Diário da República n. 111/2008, Série I de 2008-06-11; Ministério do Ambiente: Lisboa, Portugal, 2008.

20. United Nations General Assembly. Report of the Special Rapporteur on the human right to safe drinking water and sanitation. Report of the Secretary-General. 3 August 2011.

21. UN special rapporteur on the human right to safe drinking water and sanitation. Realising the Human Rights to Water and Sanitation: A Handbook by the UN Special Rapporteur Catarina de Albuquerque; Lisboa, Portugal, 2014. Available online: https://www.pseau.org/outils/ouvrages/ohchr_realizing_the_human_rights_to_water_and_ sanitation_a_handbook_2014.pdf (accessed on 29 December 2019).

22. United Nations General Assembly. Human Rights Council. Report of the Special Rapporteur on the human right to safe drinking water and sanitation. UN Water. 5 August 2015.

23. United Nations Economic Commission for Europe; World Health Organization-Regional Office for Europe. Findings and Lessons Learned from the Work on Equitable Access to Water and Sanitation under the Protocol on Water and Health in the Pan-European Region; United Nations Economic Commission for Europe: Geneva, Switzerland, 2019.

24. Carvalho, P.; Simões, P.; Marques, R.C. Acessibilidade e capacidade para pagar pelos serviços de água e esgotamento sanitário em Portugal. Eng. Sanit. Ambient. 2010, 15, 325-336. [CrossRef]

25. ERSAR. Acessibilidade Económica aos Serviços Públicos de Abastecimento de Água Para Consumo Humano e de Saneamento de Águas Residuais em Portugal. Relatório ERSAR 1/2010; Entidade Reguladora da Água e Resíduos: Lisboa, Portugal, 2010.

26. Alves, D.; Carvalho, Á.C. O Acesso à água e saneamento como Direito Humano. O papel das entidades gestoras. Paper Presentation at Encontro Nacional de Entidades Gestoras, Coimbra, Portugal, 3-5 December 2013.

27. Martins, R.; Cruz, L.; Barata, E.; Quintal, C. Assessing social concerns in water tariffs. Water Policy 2013, 15, 193-211. [CrossRef]

28. Assembleia da República. Série II-A. XIII Legislatura. Sessão Legislativa 01. Número 023. 2015-12-28 (p. 21). Available online: http://debates.parlamento.pt/catalogo/r3/dar/s2a/13/01/023/2015-12-28/21?q= projeto $\% 2$ Bde $\% 2 B r e s o l u \% 25 C 3 \% 25 A 7 \% 25 C 3 \% 25$ A3o\%2B469\%252Fxii (accessed on 29 December 2019). 
29. Resolução da AR 113/2012 Título: Promove a acessibilidade, a sustentabilidade e qualidade dos serviços de abastecimento de água e de saneamento [DR I série N. ${ }^{0} 155 / X I I / 1$ 2012.08.10]. Assembleia da República: Lisboa, Portugal, 2012.

30. Resolução da AR 225/2016 Título: Recomenda ao Governo que disponibilize o mecanismo estabelecido para a atribuição automática das tarifas sociais da energia às entidades competentes em matéria de abastecimento de água [DR I série N.²19/XIII/2 2016.11.15]. Assembleia da República: Lisboa, Portugal, 2016.

31. Lei 44/2017 Título: Estabelece o princípio da não privatização do setor da água, procedendo à quinta alteração

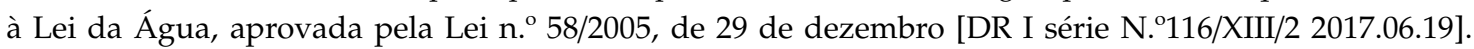
Assembleia da República: Lisboa, Portugal, 2017.

32. Ministério do Ambiente, do Ordenamento do Território e do Desenvolvimento Regional. Decreto-Lei n ${ }^{\circ}$ 194/2009. In Diário da República n. ${ }^{\circ}$ 161/2009, Série I de 2009-08-20; Ministério do Ambiente: Lisboa, Portugal, 2009.

33. Ministério do Ambiente, do Ordenamento do Território e do Desenvolvimento Regional. Decreto-lei $n^{\circ}$ 277/2009. In Diário da República n. ${ }^{\circ}$ 192/2009, Série I de 2009-10-02; Ministério do Ambiente: Lisboa, Portugal, 2009.

34. ERSAR: Missão, Atribuições e Poderes. Available online: http://www.ersar.pt/pt/a-ersar/missao-atribuicoese-poderes (accessed on 18 November 2019).

35. ERSAR "Reorganizing the Water Sector: The Portuguese Experience-Consultation with Regulators" Entidade Reguladora Do Serviço de Águas e Resíduos: Presentation by ERSAR, Portugal Made at the Regulators' and National Human Rights Institutions' Consultation on Good Practices Held in Geneva in March 2011. Available online: www.ohchr.org/Documents/Issues/Water/Consultations/Portugal_Regulator.pdf (accessed on 10 February 2015).

36. Ministério da Administração Interna. Decreto Lei n ${ }^{\circ}$ 147/2017. In Diário da República n. ${ }^{\circ}$ 233/2017, Série I de 2017-12-05; Ministério da Administração Interna: Lisboa, Portugal, 2017.

37. IRAR Recomendação 1/2009. Instituto Regulador das Águas e Resíduos: Lisboa, Portugal, 2009.

38. Águas da Covilhã. Regulamento Municipal de Água e Águas Residuais da Covilhã. Águas da Covilhã: Covilhã, Portugal, 2014.

39. Câmara Municipal de Póvoa do Lanhoso. Regulamento 502/2012. Regulamento Municipal de Abastecimento de Água e Drenagem de Águas Residuais Urbanas; Câmara Municipal de Póvoa do Lanhoso: Póvoa do Lanhohso, Portugal, 2012. Available online: https://dre.pt/application/conteudo/3359647 (accessed on 10 February 2015).

40. AdPlanalto (2015) Tarifário 2015-Águas do Planalto, S.A.. Available online: http://www.aguasdoplanalto.pt/ index.php?tipo $=$ clientes19\&id=19\&pai=clientes (accessed on 10 February 2015).

41. APFN (n.d.) Associação Portuguesa de Famílias Numerosas: Caderno 1. Available online: https://www.apfn.com. pt/Cadernos/Caderno1/caderno1.htm (accessed on 10 February 2015).

42. CMVNFamalicão (2015) Regulamento de Distribuição de Água e de Drenagem de Águas Resíduais. Available online: http://www.vilanovadefamalicao.org/op/document/?co=1028\&h=b9262 (accessed on 10 February 2015).

43. INT1 (2014) Interview with a High-Level Administrative of the Water Utility. Guarda, 23 December 2014.

44. Cartágua (2014) Tarifário 2014—Cartágua, S.A.. Available online: http://www.cartagua.pt/wp-content/uploads/ 2014/03/tarifario_cartaxo_2014.pdf (accessed on 10 February 2015).

45. CMManteigas (2009) Regulamento do Cartão do Idoso. Available online: https://dre.pt/home/-/dre/72797280/ details/maximized (accessed on 10 February 2015).

46. INT2 (2014) Interview with a responsible of the Social Security. Coimbra, 20 November 2014.

47. INT3 (2014) Interview with a high-level administrative of the private water utility. Aveiro, 12 December 2014.

48. INT4 (2014) Interview with a local political representative. Penela, 13 November 2014.

49. INT5 (2014) Interview with a high-level administrative of the municipal water utility. Castelo de Vide, 22 December 2014.

50. INT6 (2014) Interview with a local elected representative. Soure, 7 November 2014.

51. INT7 (2014) Interview with a local elected representative. Mira, 7 November 2014.

52. INT8 (2014) Interview with a local elected representative. Penamacor, 22 December 2014.

53. INT9 (2014) Interview with a technical staff of the water utility. Poiares, 5 November 2014.

54. INT10 (2015) Interview with a high-level administrative of the water services. Maia, 28 January 2015.

55. INT11 (2014) Interview with a high-level administrative of the water services. Oliveira do Hospital, 27 November 2014. 
56. INT12 (2014) Interview with a local elected representative. Arganil, 4 December 2014.

57. PORDATA-Base de Dados Portugal Contemporâneo. Available online: https://www.pordata.pt/en/Portugal/ Unemployment+rate+total+and+by+sex+(percentage)-550 (accessed on 29 December 2019).

58. PORDATA-Base de Dados Portugal Contemporâneo. Available online: https://www.pordata.pt/en/Portugal/ Real+GDP+growth+rate-2298 (accessed on 29 December 2019).

59. Gabinete do Secretário de Estado do Ambiente. Despacho $n^{\circ} 4385 \% 2015$. Diário da República no 84/2015, Série II de 2015-04-30; Gabinete do Secretário de Estado do Ambiente: Lisboa, Portugal, 2015.

60. Assembleia da República. Lei no 44/2017. Diário da República n. ${ }^{\circ}$ 116/2017, Série I de 2017-06-19; Assembleia da República: Lisboa, Portugal, 2017.

61. Jornal de Notícias, 26 November 2017. Available online: https://www.jn.pt/local/noticias/porto/porto/dezenasde-familias-em-aldoar-ficam-sem-agua-8922873.html (accessed on 29 December 2019).

62. Dinheiro Vivo. 25 November 2018. Available online: https://www.dinheirovivo.pt/iniciativas/catarina-dealbuquerque-o-problema-em-portugal-e-que-nao-se-ganha-bem/ (accessed on 29 December 2019).

63. EurEau. Access to Water and Measures in Case of Non-Payment. Briefing Note. 26 August 2016. Available online: http://www.eureau.org/resources/position-papers/137-access-to-water-and-measures-in-case-ofnon-payment-august2016/file (accessed on 13 February 2020).

(C) 2020 by the author. Licensee MDPI, Basel, Switzerland. This article is an open access article distributed under the terms and conditions of the Creative Commons Attribution (CC BY) license (http://creativecommons.org/licenses/by/4.0/). 